\title{
PERSEPSI MASYARAKAT TERHADAP PENGELOLAAN EKOWISATA BAHARI DI DESA BAHOI, KECAMATAN LIKUPANG BARAT, KABUPATEN MINAHASA UTARA, PROVINSI SULAWESI UTARA
}

\author{
Ghea Meily Gloria Pangau 1; Jardie A. Andaki²; Vonne Lumenta ${ }^{2}$ \\ 1) Mahasiswa Fakultas Perikanan dan Ilmu Kelautan Universitas Sam Ratulangi, Manado. \\ 2) Staff Pengajar Fakultas Perikanan dan IImu Kelautan Universitas Sam Ratulangi, Manado. \\ Koresponden email: gepangau@yahoo.com
}

\begin{abstract}
This study uses a descriptive approach, ie a study that leads to the disclosure of a problem or situation as it is and reveals the facts that exist, although sometimes given interpretation or analysis (Tika, 2005). According Kusmayadi (2000), descriptive research is research that try to describe or describe phenomena and relationship between phenomena studied with systematic, factual, and accurate.

Based on population data in 2014 Bahoi Village population amounted to 439 inhabitants, consisting of 143 heads of household (KK) divided into 3 guard boundaries. Determination of the sample by purposive as much as $20 \%$ from 439 soul that is 90 villagers divided by marine ecotourism managers, managers of Marine Protected Areas, village apparatus and villagers who utilize the existence of marine ecotourism.

Data collection techniques were conducted by observation, interview and questionnaire. While the data analysis technique used is descriptive analysis. The data obtained in the study is made in a simpler form for easy understanding. Data are presented in the form of frequency tables and percentages, then described.

Overall, it can be concluded that community perception on marine ecotourism management in Bahoi Village, West Likupang District, and North Minahasa Regency North Sulawesi Province is good.

Based on the results of research and discussion that has been done shows that community perception of marine ecotourism management planning of Bahoi Village West Likupang District North Mianahasa Regency North Sulawesi Province that most of respondents expressed very good on life support ability, both at source data and management information available SDA data and information, as well as regional characteristics.

Public perceptions on the use of marine ecotourism that most of the respondents stated both on the sustainability of the function of sustainability, productivity and community welfare.

Public perceptions of marine ecotourism control of Bahoi Village, West Likupang District, North Minahasa District, North Sulawesi Province, mostly respondents stated good prevention, preventive role, countermeasures and countermeasures. Public Perceptions of Marine Ecotourism Maintenance in Bahoi Village most of the respondents stated good.

Public perceptions of law enforcement in marine ecotourism areas in Bahoi Village are the majority of respondents stated very well on the complaint, and stated both on the socialization of complaints, law enforcement.

Keywords: management, marine ecotourism, community perception
\end{abstract}

\begin{abstract}
Abstrak
Penelitian ini menggunakan pendekatan deskriptif, yaitu suatu penelitian yang mengarah pada pengungkapan suatu masalah atau keadaan sebagaimana adanya dan mengungkapkan fakta-fakta yang ada, walaupun kadang-kadang diberikan interpretasi atau analisis (Tika, 2005). Menurut Kusmayadi (2000), penelitian deskriptif adalah penelitian yang berusaha mendeskripsikan atau menggambarkan fenomena serta hubungan antar fenomena yang diteliti dengan sistematis, faktual, dan akurat.

Berdasarkan data kependudukan tahun 2014 jumlah Penduduk Desa Bahoi berjumlah 439 jiwa, terdiri dari 143 kepala keluarga (KK) yang dibagi dalam 3 batas jaga. Penentuan sampel secara purposive sebanyak $20 \%$ dari 439 jiwa yaitu 90 warga desa yang dibagi atas pengelola ekowisata bahari, pengelola Daerah Perlindungan Laut, aparatur desa dan warga desa yang memanfaatkan keberadaan ekowisata bahari.

Teknik pengumpulan data dilakukan dengan observasi, wawancara dan kuesioner. Sedangkan teknik analisis data yang digunakan adalah analisis deskriptif. Data yang diperoleh dalam penelitian dibuat dalam bentuk yang lebih sederhana agar mudah dipahami. Data disajikan dalam bentuk tabel frekuensi dan persentase, kemudian dideskripsikan.

Secara keseluruhan dapat disimpulkan bahwa persepsi masyarakat terhadap pengelolaan ekowisata bahari di Desa Bahoi Kecamatan Likupang Barat Kabupaten Minahasa Utara Provinsi Sulawesi Utara tergolong baik.

Berdasarkan hasil penelitian dan pembahasan yang telah dilakukan menunjukkan, bahwa persepsi masyarakat terhadap perencanaan pengelolaan ekowisata bahari Desa Bahoi Kecamatan Likupang Barat Kabupaten Mianahasa Utara Provinsi Sulawesi Utara yakni sebagian besar responden menyatakan sangat baik pada kemampuan mendukung kehidupan, baik pada sumber data dan informasi pengelolaan, sumber data dan informasi SDA yang tersedia, serta karakteristik wilayah.

Persepsi masyarakat terhadap pemanfaatan ekowisata bahari yakni sebagian besar responden menyatakan baik pada keberlanjutan fungsi keberlanjutan, produktivitas dan kesejahteraan masyarakat.
\end{abstract}


Persepsi masyarakat terhadap pengendalian ekowisata bahari Desa Bahoi Kecamatan Likupang Barat Kabupaten Minahasa Utara Provinsi Sulawesi Utara yakni sebagian besar responden menyatakan baik pada upaya pencegahan, peran pencegahan, upaya penanggulangan dan peran penanggulangan. Persepsi Masyarakat terhadap Pemeliharaan Ekowisata Bahari di Desa Bahoi sebagian besar responden menyatakan baik.

Persepsi masyarakat terhadap penegakan hukum pada kawasan ekowisata bahari di Desa Bahoi yakni sebagian besar responden menyatakan sangat baik pada pengaduan, dan menyatakan baik pada sosialisasi pengaduan, penegakan hukum.

Kata kunci: pengelolaan, ekowisata bahari, persepsi masyarakat

\section{PENDAHULUAN}

Ekowisata bahari merupakan suatu usaha yang dapat menghasilkan berbagai produk pariwisata berdasarkan sumberdaya alam yang pengelolaan ekowisata merupakan salah satu bentuk alternatif untuk meminimalkan dampak terhadap lingkungan hidup, sumbangan kepada upaya konservasi dan meningkatkan kesejahteraan untuk masyarakat lokal. Pengelolaan ekowisata bertujuan untuk menyediakan kualitas pengalaman wisatawan dan meningkatkan kualitas hidup masyarakat lokal (Fahriansyah dan Yoswaty, 2012).

Desa Bahoi merupakan Desa yang memiliki Daerah Perlindungan Laut (DPL) dan Kelompok Kerajinan tangan, kawasan mangrove dan laut yang dilindungi di Desa Bahoi sangat berarti bagi masyarakat Desa Bahoi yang lebih dari $50 \%$ penduduknya adalah nelayan. Masyarakat Desa Bahoi percaya bahwa kawasan yang dilindungi ini merupakan daerah untuk pemijahan berbagai jenis ikan.

Kesadaran masyarakat dalam pengelolaan di satu wilayah sangatlah penting. Dian dan Hapsari (2012), menyatakan bahwa peningkatan kesadaran masyarakat dalam pengelolaan suatu kawasan sangat penting demi keberhasilan upaya pengelolaan pada kawasan tertentu. Penelitian akan menganalisis persepsi masyarakat Desa Bahoi terhadap pengelolaan ekowisata bahari. Analisis persepsi masyarakat desa sangat menentukan apakah masyarakat mengerti tentang pentingnya kawasan ekowisata bahari bagi kelangsungan hidup masyarakat dan lingkungan pesisir dalam kaitan dengan pengelolaan kawasan ekowisata bahari agar tetap lestari.

\section{Perumusan Masalah}

Rumusan masalah dalam penelitian ini yaitu :

1. Apa saja peranan masyarakat desa terhadap pengelolaan ekowisata bahari di Desa Bahoi?

2. Bagaimana persepsi masyarakat Desa Bahoi terhadap pengelolaan ekowisata bahari di Desa Bahoi?

\section{Tujuan Penelitian}

Tujuan penelitian ini, yaitu :

1. Mengetahui berbagai peran masyarakat dalam pengelolaan ekowisata bahari di Desa Bahoi

2. Mengetahui persepsi masyarakat terhadap pengelolaan ekowisata bahari di Desa Bahoi

\section{Tempat dan Waktu Penelitian}

Penelitian ini dilaksanakan di Desa Bahoi Kecamatan Likupang Barat Kabupaten Minahasa Utara.Waktu yang diperlukan dalam melaksanakan penelitian ini mulai dari rencana penyusunan rencana kerja Penelitian sampai pada pelaksanaan ujian dari bulan Februari sampai April 2018.

\section{METODE PENELITIAN}

Penelitian ini menggunakan pendekatan deskriptif, yaitu suatu penelitian yang mengarah pada pengungkapan suatu masalah atau 
keadaan sebagaimana adanya dan mengungkapkan fakta-fakta yang ada, walaupun kadang-kadang diberikan interpretasi atau analisis (Tika, 2005). Menurut Kusmayadi (2000), penelitian deskriptif adalah penelitian yang berusaha mendeskripsikan atau menggambarkan fenomena serta hubungan antar fenomena yang diteliti dengan sistematis, faktual, dan akurat.

Berdasarkan bentuk dan metode penelitiannya, penelitian ini menggunakan teknik survei. Ciri khas penelitian ini adalah data dikumpulkan dari responden yang banyak jumlahnya dengan menggunakan kuesioner. Salah satu keuntungan utama dari penelitian ini adalah mungkinnya pembuatan generalisasi untuk populasi yang besar (Masri dan Sofian, 2006). Menurut Hasan (2010), penelitian survei adalah penelitian yang tidak melakukan perubahan (tidak ada perlakuan khusus) terhadap variabel-variabel yang diteliti.

Penelitian ini membahas tentang Persepsi masyarakat terhadap pengelolaan ekowisata bahari di Desa Bahoi, Kecamatan Likupang Barat, Kabupaten Minahasa Utara, Provinsi Sulawesi Utara dengan menggunakan tabel frekuensi.

Variabel penelitian ini adalah persepsi masyarakat terhadap pengelolaan ekowisata bahari, yang meliputi indikator:

a. Persepsi masyarakat terhadap perencanaan.

b. Persepsi masyarakat terhadap perencanaan adalah penilaian masyarakat terhadap upaya internalisasi aspek ekowisata bahari ke dalam perencanaan dan penyelenggaraan pembangunan Desa Bahoi meliputi inventarisasi lingkungan hidup, penetapan wilayah ekoregion, dan pembangunan berkelanjutan

c. Persepsi masyarakat terhadap pemanfaatan.

d. Persepsi masyarakat terhadap pemanfaatan adalah penilaian masyarakat terhadap pemanfaatan sumber daya alam yang dilaksanakan berdasarkan daya dukung dan daya tampung pada kawasan ekowisata bahari Desa Bahoi meliputi keberlanjutan fungsi, produktivitas, dan kesejahteraan masyarakat.

e. Persepsi masyarakat terhadap pengendalian.

f. Persepsi masyarakat terhadap pengendalian adalah penilaian masyarakat terhadap pengendalian kerusakan kawasan ekowisata bahari di Desa Bahoi meliputi pencegahan dan penanggulangan.

g. Persepsi masyarakat terhadap pemeliharaan.

h. Persepsi masyarakat terhadap pemeliharaan adalah penilaian masyarakat terhadap upaya yang dilakukan untuk menjaga pelestarian fungsi pada kawasan ekowisata bahari dan mencegah terjadinya penurunan atau kerusakan pada kawasan ekowisata bahari di Desa Bahoi yang disebabkan oleh perbuatan manusia berupa upaya konservasi sumber daya alam.

i. Persepsi masyarakat terhadap penegakan hukum.

j. Persepsi masyarakat terhadap penegakan hukum adalah penilaian masyarakat terhadap penegakan hukum pelaku tindak pidana pada kawasan ekowisata bahari di Desa Bahoi meliputi pengaduan, sosialisasi kebijakan pengaduan, selanjutnya penegakan hukum kepada tindak pidana pada kawasan ekowisata bahari di Desa Bahoi. 
Pengambilan sampel untuk dijadikan responden dilakukan dengan teknik Purposive sampling. Menurut Sugiyono (2010), Purposive sampling adalah teknik untuk menentukan sampel penelitian dengan beberapa pertimbangan tertentu yang bertujuan agar data yang diperoleh nantinya bisa lebih representative.

Pertimbangan dalam hal ini ialah masyarakat Desa Bahoi yang mengerti tentang ekowisata bahari yakni aparatur desa seperti kepala desa, sekertaris desa, kelompok perlindungan laut atau orang yang dianggap paling paham dan mengerti kondisi Desa Bahoi.

Berdasarkan data kependudukan tahun 2014 jumlah Penduduk Desa Bahoi berjumlah 439 jiwa, terdiri dari 143 kepala keluarga (KK) yang dibagi dalam 3 batas jaga. Penentuan sampel secara purposive sebanyak 20\% dari 439 jiwa yaitu 90 warga desa yang dibagi atas pengelola ekowisata bahari, pengelola Daerah Perlindungan Laut, aparatur desa dan warga desa yang memanfaatkan keberadaan ekowisata bahari.

Teknik pengumpulan data dilakukan dengan observasi, wawancara dan kuesioner. Sedangkan teknik analisis data yang digunakan adalah analisis deskriptif. Data yang diperoleh dalam penelitian dibuat dalam bentuk yang lebih sederhana agar mudah dipahami. Data disajikan dalam bentuk tabel frekuensi dan persentase, kemudian dideskripsikan.

\section{HASIL DAN PEMBAHASAN}

\section{Persepsi Masyarakat terhadap Perencanaan}

Persepsi masyarakat terhadap perencanaan merupakan penilaian masyarakat terhadap upaya internalisasi aspek ekowisata bahari ke dalam perencanaan

Penyelenggaraan pembangunan di Desa Bahoi meliputi inventarisasi ekowisata bahari dan penetapan wilayah ekoregion.

\section{Inventarisasi Ekowisata Bahari}

Inventarisasi ekowisata bahari meliputi data informasi pengelolaan, dan informasi sumber daya alam yang ada di Desa Bahoi

\section{Data dan Informasi Pengelolaan}

Persepsi masyarakat terhadap data dan informasi pengelolaan dapat dilihat berdasarkan tabel berikut.

Tabel 1. Persepsi Masyarakat terhadap Data dan Informasi Pengelolaan

\begin{tabular}{|c|l|c|c|}
\hline No. & Persepsi & Jumlah & Persentase \\
\hline 1. & Sangat baik & 8 & 8,89 \\
\hline 2. & Baik & 73 & 81,11 \\
\hline 3. & Tidak baik & 9 & 10 \\
\hline \multicolumn{2}{|c|}{ Jumlah } & 90 & 100,00 \\
\hline
\end{tabular}

Sumber: Data Primer Tahun 2018

Sebagian besar responden $(81,11 \%)$ menyatakan data dan informasi pengelolaan baik, karena responden sering memperoleh data dan informasi pengelolaan melalui sosialisasi dari pemerintah desa yang di sampaikan oleh kepala jaga dan maweteng, atau melalui musyawarah bersama dengan masyarakat desa. (10\%) responden yang menyatakan tidak baik terhadap data dan informasi pengelolaan rata-rata merupakan responden yang sama yang memang kurang setuju terhadap pengelolaan ekowisata bahari yang dilakukan oleh pemerintah Desa Bahoi.

\section{Data dan Informasi Sumber Daya Alam \\ Persepsi masyarakat terhadap data dan informasi sumber daya alam dapat diketahui berdasarkan tabel berikut.}


Tabel 2. Persepsi Masyarakat terhadap Data dan Informasi Sumber Daya Alam

\begin{tabular}{|c|l|c|c|}
\hline No. & Persepsi & Jumlah & Persentase \\
\hline 1. & Sangat baik & 12 & 13,33 \\
\hline 2. & Baik & 71 & 78,89 \\
\hline 3. & Tidak baik & 7 & 7,78 \\
\hline \multicolumn{2}{|c|}{ Jumlah } & 90 & 100,00 \\
\hline
\end{tabular}

Sumber: Data Primer Tahun 2018

Sebagian besar responden $(78,89 \%)$ menyatakan data dan informasi sumber daya alam baik, karena responden mendapatkan informasi terkait ketersediaan sumber daya alam baik melalui sosialisasi dari kelompok - kelompok pengelola maupun pemerintah daerah. $(7,78 \%)$ responden menyatakan tidak baik terhadap data dan informasi sumber daya alam, responden yang memilih jawaban tidak baik terhadap variabel-variabel yang diteliti merupakan responden yang sama, sehingga menyebabkan adanya presentasi jawaban tidak setuju di setiap variabel penelitian.

\section{Penetapan Wilayah Ekoregion}

Ekoregion adalah pola susunan berbagai ekosistem dan proses di antara ekosistem tersebut yang terkait dalam satu satuan geografis. Penetapan wilayah ekoregion meliputi karakteristik wilayah dan kemampuan mendukung kehidupan di Desa Bahoi

\section{Karakteristik Wilayah}

Pengelolaan ekowisata bahari harus mempertimbangkan karakteristik bentang alam, iklim, sosial budaya, ekonomi, kelembagaan masyarakat. Persepsi masyarakat terhadap pengelolaan ekowisata bahari sesuai karakteristik wilayah dapat diketahui berdasarkan tabel berikut.

Tabel 3. Persepsi Masyarakat terhadap Karakteristik Wilayah

\begin{tabular}{|l|l|l|l|}
\hline No. & Persepsi & Jumlah & Persentase \\
\hline
\end{tabular}

\begin{tabular}{|r|l|c|r|}
\hline 1. & Sangat baik & 23 & 25,56 \\
\hline 2. & Baik & 61 & 67,78 \\
\hline 3. & Tidak baik & 6 & 6,66 \\
\hline \multicolumn{2}{|c|}{ Jumlah } & 90 & 100,00 \\
\hline
\end{tabular}

Sumber: Data Primer Tahun 2018

Sebagian besar responden $(67,78 \%)$ menyatakan pengelolaan ekowisata bahari sudah baik karena sesuai dengan karakteristik wilayah Desa Bahoi, $(6,66 \%)$ responden menyatakan tidak baik terhadap karakteristik wilayah, responden yang memilih jawaban tidak baik terhadap variabel-variabel yang diteliti merupakan responden yang sama, sehingga menyebabkan adanya presentasi jawaban tidak setuju di setiap variabel penelitian.

\section{Kemampuan Mendukung Kehidupan}

Persepsi masyarakat terhadap kemampuan kawasan ekowisata bahari dalam mendukung kehidupan dapat diketahui berdasarkan tabel berikut.

Tabel 4. Persepsi Masyarakat terhadap Kemampuan Mendukung Kehidupan

\begin{tabular}{|c|l|c|r|}
\hline No. & Persepsi & Jumlah & Persentase \\
\hline 1. & Sangat baik & 59 & 65,56 \\
\hline 2. & Baik & 21 & 23,33 \\
\hline 3. & Tidak baik & 10 & 11,11 \\
\hline \multicolumn{2}{|c|}{ Jumlah } & 90 & 100,00 \\
\hline
\end{tabular}

Sumber: Data Primer Tahun 2018

Sebagian besar responden $(65,56 \%)$ menyatakan kemampuan ekowisata bahari dalam mendukung kehidupan sangat baik. (11,11\%) responden menyatakan tidak baik terhadap kemampuan mendukung kehidupan, responden yang memilih jawaban tidak baik terhadap variabelvariabel yang diteliti merupakan responden yang sama, sehingga menyebabkan adanya presentasi jawaban tidak setuju di setiap variabel penelitian. Penting untuk mengetahui persepsi masyarakat terhadap 
kemampuan kawasan ekowisata bahari dalam mendukung kehidupan karena dapat mengukur seberapa besar pengetahuan dan kesadaran masyarakat akan pentingnya kawasan ekowisata bahari, jika dikelola dan dijaga dengan baik

\section{Persepsi Masyarakat terhadap Pemanfaatan}

Persepsi masyarakat terhadap permanfaatan merupakan penilaian masyarakat terhadap pemanfaatan sumber daya alam yang dilaksanakan berdasarkan daya dukung dan daya tampung pada kawasan ekowisata bahari Desa Bahoi meliputi keberlanjutan fungsi, keberlanjutan produktivitas, dan kesejahteraan masyarakat.

\section{Keberlanjutan Fungsi}

Persepsi masyarakat terhadap pemanfaatan sumber daya alam sesuai dengan fungsinya dapat diketahui berdasarkan tabel berikut.

Tabel 5. Persepsi Masyarakat terhadap Keberlanjutan Fungsi

\begin{tabular}{|c|l|c|r|}
\hline No. & Persepsi & Jumlah & Persentase \\
\hline 1 & Sangat baik & 22 & 24,45 \\
\hline 2 & Baik & 56 & 62,22 \\
\hline 3 & Tidak baik & 12 & 13,33 \\
\hline \multicolumn{2}{|c|}{ Jumlah } & 90 & 100,00 \\
\hline
\end{tabular}

Sumber: Data Primer 2018

Sebagian besar responden $(62,22 \%)$ menyatakan pemanfaatan sumber daya alam sudah baik karena sesuai dengan fungsinya. (13,33\%) responden menyatakan tidak baik terhadap keberlanjutan fungsi, responden yang memilih jawaban tidak baik terhadap variabel-variabel yang diteliti merupakan responden yang sama, sehingga menyebabkan adanya presentasi jawaban tidak setuju di setiap variabel penelitian. Penting untuk mengetahui persepsi masyarakat terhadap kesesuian pemanfaatan kawasan ekowisata bahari dengan fungsinya, pertanyaan ini dapat mengukur apakah masyarakat mengerti akan pentingnya perlindungan dan pengelolaan ekowisata bahari dan bagaimana masyarakat memanfaatkan kawasan ekowisata bahari sesuai dengan fungsinya.

\section{Keberlanjutan Produktivitas}

Persepsi masyarakat terhadap pemanfaatan sumber daya alam pada kawasan ekowisata bahari dapat diketahui berdasarkan tabel berikut.

Tabel 6. Persepsi Masyarakat terhadap Keberlanjutan Produktivitas

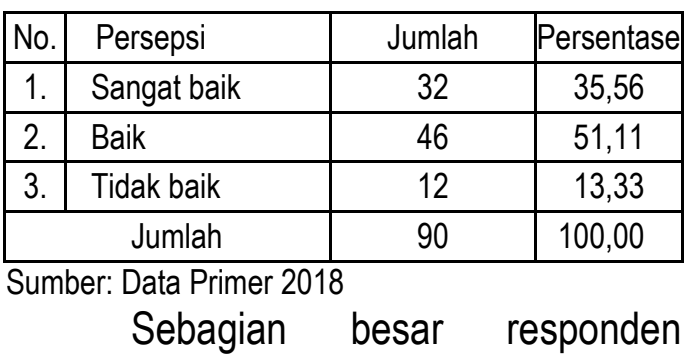
$(51,11 \%)$ menyatakan pemanfaatan sumber daya alam memperhatikan pelestarian lingkungan pada kawasan ekowisata bahari. (13,33\%) responden menyatakan tidak baik terhadap pemanfaatan sumber daya alam sangat memperhatikan pelestarian lingkungan, responden yang memilih jawaban tidak baik terhadap variabel-variabel yang diteliti merupakan responden yang sama, sehingga menyebabkan adanya presentasi jawaban tidak setuju di setiap variabel penelitian. Penting untuk mengetahui persepsi masyarakat mengenai bagaimana pelestarian likungan dalam pemanfaatan sumberdaya alam di kawasan ekowisata bahari, pertanyaan ini dapat mengukur kesadaran masyarakat untuk tetap mempertahankan lingkungan hidup dalam memanfaatkan sumberdaya alam. 
Didapati bahwa masyarakat Desa Bahoi memiliki persepsi yang baik untuk memanfaatkan sumberdaya alam namun tetap menjaga sumber daya alam yang tersedia untuk masa mendatang.

\section{Kesejahteraan Masyarakat}

Persepsi masyarakat terhadap pemanfaatan sumber daya alam memperhatikan kesejahteraan masyarakat dapat diketahui berdasarkan tabel berikut.

Tabel 7. Persepsi Masyarakat terhadap Kesejahteraan Masyarakat

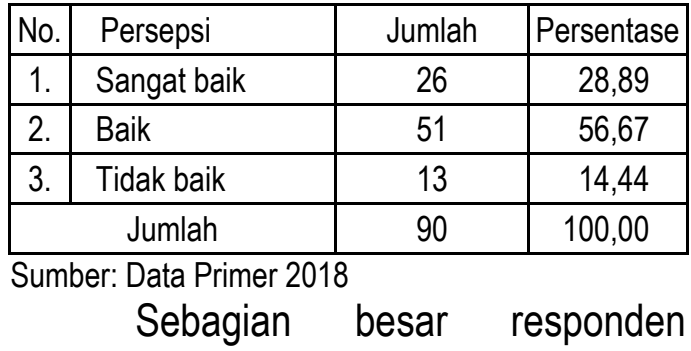
$(56,67 \%)$ menyatakan pemanfaatan sumber daya alam memperhatikan kesejahteraan masyarakat baik dengan alasan adanya perhatian lebih dari pemerintah desa terhadap kawasan ekowisata bahari melalui kebijakankebijakan yang diselenggarakan. Kepala Desa juga memperhatikan kesejahteraan dengan membuat peraturan-peraturan wilayah, contohnya pemandu wisata mangrove adalah masyarakat Desa Bahoi yang telah memiliki sertifikasi yang disahkan oleh kelompok ekowisata dan memenuhi standar pemandu wisata, hal ini dilakukan untuk menyediakan lapangan pekerjaan bagi masyarakat Desa Bahoi.

\section{Persepsi Masyarakat terhadap Pengendalian}

Persepsi masyarakat terhadap pengendalian merupakan penilaian masyarakat terhadap pengendalian kerusakan ekowisata bahari di Desa
Bahoi meliputi pencegahan dan penanggulangan.

\section{Pencegahan}

Pencegahan meliputi upaya pencegahan, dan peran masyarakat dalam pencegahan kerusakan ekowisata bahari di Desa Bahoi.

\section{Upaya Pencegahan}

Persepsi masyarakat terhadap upaya pencegahan kerusakan pada kawasan ekowisata bahari dapat diketahui berdasarkan Tabel 8.

Tabel 8. Persepsi Masyarakat terhadap Upaya Pencegahan

\begin{tabular}{|c|l|c|c|}
\hline No. & \multicolumn{1}{|c|}{ Persepsi } & Jumlah & Persentase \\
\hline 1. & Sangat baik & 31 & 34,44 \\
\hline 2. & Baik & 53 & 58,89 \\
\hline 3. & Tidak baik & 6 & 6,67 \\
\hline \multicolumn{2}{|c|}{ Jumlah } & 90 & 100,00 \\
\hline
\end{tabular}

Sumber: Data Primer 2018

Sebagian besar responden $(58,89 \%) \quad$ menyatakan upaya pencegahan dinyatakan baik. Upaya pencegahan yang dilakukan yakni mengadakan sosialisasi berkala untuk menjaga kondisi kawasan ekowisata bahari dari kerusakan. Sebagian masyarakat lainnya menilai bahwa upaya pencegahan tidak baik, hal ini dikarenakan masyarakat menilai kebijakan yang ada saat ini hanya menguntungkan beberapa kelompok saja.

\section{Peran Pencegahan}

Persepsi masyarakat terhadap peran masyarakat dalam pencegahan kerusakan pada kawasan ekowisata bahari dapat diketahui berdasarkan Tabel 9. 
Tabel 9. Persepsi Masyarakat terhadap Peran Pencegahan

\begin{tabular}{|c|l|c|c|}
\hline No. & Persepsi & Jumlah & Persentase \\
\hline 1. & Sangat baik & 26 & 28,89 \\
\hline 2. & Baik & 60 & 66,67 \\
\hline 3. & Tidak baik & 4 & 4,44 \\
\hline \multicolumn{2}{|c|}{ Jumlah } & 90 & 100,00 \\
\hline
\end{tabular}

Sumber: Data Primer 2018

Sebagian besar responden $(66,67 \%)$ menyatakan peran masyarakat baik. $(4,44 \%)$ responden menyatakan tidak baik terhadap peran masyarakat, responden yang memilih jawaban tidak baik terhadap variabel-variabel yang diteliti merupakan responden yang sama, sehingga menyebabkan adanya presentasi jawaban tidak setuju di setiap variabel penelitian. Persepsi masyarakat Desa Bahoi terhadap peran masyarakat dalam upaya pencegahan kerusakan pada kawasan ekowisata bahari pertanyaan ini melihat apakah masyarakat berperan aktiv dalam upaya pencegahan pada kawasan ekowisata bahari.

\section{Penangulangan}

Penangulangan meliputi upaya penangulangan dan peran masyarakat dalam penagulangan kerusakan pada kawasan ekowisata bahari di Desa Bahoi.

\section{Upaya Penagulangan}

Persepsi masyarakat terhadap penagulangan kerusakan pada kawasan ekowisata bahari dapat diketahui berdasarkan Tabel 10.

Tabel 10. Persepsi Masyarakat terhadap Upaya Penanggulangan

\begin{tabular}{|c|l|c|c|}
\hline No. & \multicolumn{1}{|c|}{ Persepsi } & Jumlah & Persentase \\
\hline 1. & Sangat baik & 24 & 26,67 \\
\hline 2. & Baik & 57 & 63,33 \\
\hline 3. & Tidak baik & 9 & 10 \\
\hline \multicolumn{2}{|c|}{ Jumlah } & 90 & 100,00 \\
\hline
\end{tabular}

Data : Primer 2018
Sebagian besar responden $(63,33 \%) \quad$ menyatakan upaya penangulangan baik. Upaya penangulangan yang dilakukan pemerintah Desa terus melakukan sosialisasi kepada masyarakat untuk menjaga kebersian dan tidak melakukan tindakan pengursakan pada kawasan ekowisata bahari seperti melaukan penebangan pohon mangrove secara liar tanpa melapor kepada kelompok pengelola dan pemerintah Desa. Untuk sampah kiriman seperti botol/gelas pelastik dikumpulkan masyarakat Desa Bahoi kemudian dijual untuk menambah penghasilan.

\section{Peran Penanggulangan}

Persepsi masyarakat terhadap peran masyarakat dalam penanggulangan kerusakan pada kawasan ekowisata bahari dapat diketahui berdasarkan tabel berikut.

Tabel 11. Persepsi Masyarakat terhadap Peran Penanggulangan

\begin{tabular}{|c|l|c|c|}
\hline No. & \multicolumn{1}{|c|}{ Persepsi } & Jumlah & Persentase \\
\hline 1. & Sangat baik & 25 & 27,78 \\
\hline 2. & Baik & 58 & 64,44 \\
\hline 3. & Tidak baik & 7 & 7,78 \\
\hline \multicolumn{2}{|c|}{ Jumlah } & 90 & 100,00 \\
\hline
\end{tabular}

Sumber: Data Primer 2018

Sebagian besar responden $(64,44 \%)$ menyatakan peran masyarakat baik. Sebagian masyarakat Desa Bahoi sangat taat akan peraturan desa yang melarang tindakan yang pengrusakan pada kawasan ekowisata bahari, misalnya dengan tidak melakukan penebangan mangrove secara liar tanpa melapor kepada kelompok pengelola dan pemerintah Desa. Berdasarkan hasil penelitian masyarakat Desa Bahoi sudah mengerti akan pentingnya untuk menjaga kawasan ekowisata bahari sehingga penebangan pohon mangrove secara liar sudah tidak dilakukan oleh 
masyarakat karena masyarakat sudah merasakan secara langsung hasil dari pengelolaan pada kawasan ekowisata bahari.

\section{Persepsi Masyarakat terhadap Pemeliharaan}

Persepsi masyarakat terhadap pemeliharaan merupakan penilaian masyarakat terhadap upaya yang dilakukan untuk menjaga pelestarian pada kawasan ekowisata bahari dan mencegah terjadinya penurunan atau kerusakan pada kawasan ekowisata bahari yang disebabkan oleh perbuatan manusia di Desa Bahoi, berupa upaya konservasi sumber daya alam.

Tabel 12. Persepsi Masyarakat terhadap Pemeliharaan

\begin{tabular}{|c|c|c|c|}
\hline No. & Persepsi & Jumlah & Persentase \\
\hline 1. & Sangat baik & 32 & 35,56 \\
\hline 2. & Baik & 53 & 58,89 \\
\hline 3. & Tidak baik & 5 & 5,55 \\
\hline & Jumlah & 90 & 100,00 \\
\hline
\end{tabular}

Sumber: Data Primer 2018

Sebagian besar responden $(58,89 \%)$ menyatakan pemeliharaan baik. Masyarakat menilai bahwa pengawasan begitu ketat yang dilakukan oleh pemerintah desa dan kelompok pengelola untuk melindungi dan memelihara kawasan ekowisata bahari. Penting untuk mengetahui persepsi masyarakat terhadap upaya konservasi sumber daya alam pada kawasan ekowisata bahari.

\section{Persepsi Masyarakat terhadap Penegakan Hukum}

Persepsi masyarakat terhadap penegakan hukum merupakan penilaian masyarakat terhadap penegakan hukum bagi pelaku yang tidak taat pada Peraturan Desa (Perdes). Meliputi pengaduan, sosialisasi kebijakan pengaduan, dan penegakan hukum.

\section{Peran Masyarakat dalam Pengaduan}

Persepsi masyarakat terhadap peran masyarakat dalam pengaduan pencemaran dan kerusakan pada kawasan ekowisata bahari dapat diketahui berdasarkan tabel berikut.

Tabel 13. Persepsi Masyarakat terhadap Pengaduan

\begin{tabular}{|c|l|c|r|}
\hline No. & \multicolumn{1}{|c|}{ Persepsi } & Jumlah & Persentase \\
\hline 1. & Sangat baik & 55 & 61,11 \\
\hline 2. & Baik & 32 & 35,56 \\
\hline 3. & Tidak baik & 3 & 3,33 \\
\hline Jumlah & 90 & 100,00 \\
\hline
\end{tabular}

Paling banyak responden $(61,11 \%)$ menyatakan peran masyarakat sangat baik. Karena rata-rata masyarakat Desa Bahoi sangat peduli akan kawasan ekowisata bahari, sehingga masyarakat turut berperan aktiv dalam melaporkan pengaduan kepada pemerintah desa jika ada masyarakat Desa Bahoi atau masyarakat dari desa lain yang melakukan perusakan pada kawasan ekowisata bahari.

\section{Sosialisasi Pengaduan}

Persepsi masyarakat terhadap sosialisasi pengaduan dapat diketahui berdasarkan tabel berikut.

Tabel 14. Persepsi Masyarakat terhadap Sosialisasi Pengaduan

\begin{tabular}{|c|c|c|c|}
\hline No. & Persepsi & Jumlah & Persentase \\
\hline 1. & Sangat baik & 19 & 21,11 \\
\hline 2. & Baik & 65 & 72,22 \\
\hline 3. & Tidak baik & 6 & 6,67 \\
\hline & Jumlah & 90 & 100,00 \\
\hline
\end{tabular}

Sumber: Data Primer 2018

Sebagian besar responden $(72,22 \%)$ menyatakan sosialisasi pengaduan kepada masyarakat baik. Menurut masyarakat Desa Bahoi, pemerintah desa terus melakukan sosialisasi kepada masyarakat baik 
melaui Kepala Jaga, Maweteng dan kelompok pengelola.

\section{Penegakan Hukum}

Persepsi masyarakat terhadap penegakan hukum oleh pemerintah desa dapat diketahui berdasarkan tabel berikut.

Tabel 15. Persepsi Masyarakat terhadap Penegakan Hukum

\begin{tabular}{|c|l|c|c|}
\hline No. & \multicolumn{1}{|c|}{ Persepsi } & Jumlah & Persentase \\
\hline 1. & Sangat baik & 24 & 26,67 \\
\hline 2. & Baik & 57 & 63,33 \\
\hline 3. & Tidak baik & 9 & 10 \\
\hline \multicolumn{2}{|r|}{ Jumlah } & 90 & 100,00 \\
\hline
\end{tabular}

Sumber: Data Primer 2018

Sebagian besar responden $(63,33 \%)$ menyatakan penegakan hukum berjalan dengan baik. Karena peerintah Desa Bahoi sangat tegas menegakkan hukum kepada masyarakat yang melakukan tindakan pengrusakan yang melanggar PERDES.

\section{KESIMPULAN DAN SARAN \\ Kesimpulan}

Secara keseluruhan dapat disimpulkan bahwa persepsi masyarakat terhadap pengelolaan ekowisata bahari di Desa Bahoi Kecamatan Likupang Barat Kabupaten Minahasa Utara Provinsi Sulawesi Utara tergolong baik.

Berdasarkan hasil penelitian dan pembahasan yang telah dilakukan menunjukkan, bahwa persepsi masyarakat terhadap perencanaan pengelolaan ekowisata bahari Desa Bahoi Kecamatan Likupang Barat Kabupaten Mianahasa Utara Provinsi Sulawesi Utara yakni sebagian besar responden menyatakan sangat baik pada kemampuan mendukung kehidupan, baik pada sumber data dan informasi pengelolaan, sumber data dan informasi SDA yang tersedia, serta karakteristik wilayah.
Persepsi masyarakat terhadap pemanfaatan ekowisata bahari yakni sebagian besar responden menyatakan baik pada keberlanjutan fungsi keberlanjutan, produktivitas dan kesejahteraan masyarakat.

Persepsi masyarakat terhadap pengendalian ekowisata bahari Desa Bahoi Kecamatan Likupang Barat Kabupaten Minahasa Utara Provinsi Sulawesi Utara yakni sebagian besar responden menyatakan baik pada upaya pencegahan, peran pencegahan, upaya penanggulangan dan peran penanggulangan. Persepsi Masyarakat terhadap Pemeliharaan Ekowisata Bahari di Desa Bahoi sebagian besar responden menyatakan baik.

Persepsi masyarakat terhadap penegakan hukum pada kawasan ekowisata bahari di Desa Bahoi yakni sebagian besar responden menyatakan sangat baik pada pengaduan, dan menyatakan baik pada sosialisasi pengaduan, penegakan hukum.

\section{Saran}

1. Perlu adanya sosialisasi yang lebih terhadap generasi muda di Desa Bahoi terhadap pentingnya pengelolaan ekowisata bahari.

2. Terus mengembangkan dan menjaga budaya yang ada di Desa Bahoi dalam rangka melestarikan fungsi ekowisata bahari.

\section{DAFTAR PUSTAKA}

Dahuri R., Rais J., S.P.G., Sitepu M., 2001. Pengelolaan Sumber daya Wilayah Pesisir dan Lautan Secara terpadu (Edisi Revisi). Saptodadi. Jakarta.

Dahuri, R., 2009 Strategi Pengembangan Industri Pariwisata Bahari. Jurnal Perikanan dan kelautan.

Fandeli, C., 2010. Pengusahaan Ekowisata. Fakultas Kehutanan. Universitas Gadjah mada. Yogyakarta. 
AKULTURASI

Available online :http://ejournal.unsrat.ac.id/index.php/akulturasi

Forgis Indonesia., 2016. Retrieved Maret 30, 2018, from https://id.linkedin.com/pulse/ekoregionoptimalisasi-perencanaan-perlindungan-danhidup-indonesia

Hasan, I., 2010. Analisis Data Penilaian Dengan Statistik. Jakarta: Erlangga

Juliana, 2013. Kesesuaian dan Daya Dukung Wisata Bahari Di Perairan Bandengan Kabupaten Jepara Jawa Tengah. Jurnal Perikanan dan Kelautan Tropis. Politeknik Perikanan Negeri Tual. Universitas Diponegoro Semarang. Vol. IX.

Kusamayadi, E.S., 2000. Metode Penelitian dalam Bidang Kepariwisataan. Jakarta: Gramedia Pustaka Utama.

Masri, S., Sofian, E., 2006. Metode Penelitian Survei (Editor), LP3ES, Jakarta.
Oka, A.Y., 2008. Perencanaan dan Pengembangan Pariwisata, cetakan kedua. PT. Pradnya Paramita.

Rakhmat, J., 2004. Metode Penelitian Komunikasi.Bandung : Rosdakarya

Sari, S.R., 2004. Peran Pariwisata dalam Pembangunan. Semarang: Badan Penerbit Universitas Diponegoro.

Sugiyoni., 2012. Metode Penelitian Kuantitatif Kualitatif \& RND. Bandung : Alfabeta

Tika, H.P.,2005.Metode Penelitian Geografi. Jakarta: Bumi Aksara

Tuwo, H., 2011. Pengelolaan Ekowisata Pesisir dan Laut. Brilian Internasional. Surabaya. 
AKULTURASI

Available online :http://ejournal.unsrat.ac.id/index.php/akulturasi 